\title{
Military History and Strategic Studies as Imperatives for National Security Development in Nigeria
}

\author{
Chiemela Godwin Wambu \& Amaechi Ehimatie \\ http://dx.doi./org/10.4314/ujah.v21i4.11
}

\begin{abstract}
Nigerian military history is an aspect of Nigerian history that reconstructs the philosophies, beliefs, life and times of military personnel in relation to time and place. On the other hand, strategic studies involve a study of the security policies and political conduct of states in their interaction within the international system. Since it is the military institution that implements these security policies, itself central to the objectives of states in international politics, it is logical to view military history and strategic studies as pivotal to the security development of the Nigerian nation as it is for every other nation. Given this understanding, this study attempts to situate Nigerian military history and strategic studies as imperatives for national security development in Nigeria. To achieve its goal, the paper employs mostly secondary and but a few primary sources subjected to content historical analysis from which it was deduced that military history and strategic studies are important for the advancement of security development in Nigeria.
\end{abstract}

Keywords: Military, Strategic Studies, History, Security

\section{Introduction}

Military history is an aspect of historical studies that investigates wars and organised conflict within and among states or other organised political entities. It reconstructs the philosophies, beliefs, life and times of military personnel in relation to time and place. It also investigates rationale behind certain decisions by captains and war 
commanders, most of which determine their nation's fate in certain wars. On the other hand, strategic studies involve a study of the security policies and political conduct of states in their interaction within the international system. In Nigeria as in other states, it is the military institution that implements these security policies, itself central to the objectives of state in international politics, it is logical to view military history and strategic studies as pivotal to the security development of the Nigerian nation. Given this understanding, this study attempts to situate Nigerian military history and strategic studies as imperatives for national security development in Nigeria. To achieve its goal, it employs mostly secondary and some primary sources subjected to content historical analysis from which it was deduced that military history and strategic studies are crucial for the advancement of security development in Nigeria.

\section{Military History}

During wars, every aspect of society is affected. Nations mobilize all their resources in an effort to gain victory. This entails that certain welcomed developments in national life can be brought to an abrupt end. But, the devastating effect of wars can be circumvented or reduced by knowledge of military history of the particular political enclave. Knowledge of this aspect of a people's history can serve the purposes of self evaluation, assessment, and acquaintance with military culture. Similarly, a knowledge of the country's war policy and choices, which is the subject of strategic studies, may help improve its chances of winning many wars. This is true when it is considered that national security development is a product of effective policy choices and decisions.

Wars affect all spheres of human life. They have profound effects on every aspect of societies waging them. During wars, the liberty of individuals is curtailed while the economic, political, social and religious aspects of the people's lives are reorganized to fit the 
exigencies of the war time. Because this aspect of human activity has an overall implication on human life, recording and narratives on it has to be taken seriously. It is therefore pertinent to posit that the military historian's interest is on military history which is that aspect of history that tells the story of warfare through the ages, with the aim of:

i. Determining why wars happen

ii. Examining the changes in attitude of various peoples in various ages of warfare

iii. Analysing the interaction between the military, warfare and society

iv. Examine the consequences of militarizing the societies

v. Investigating the dynamics of warfare

vi. Examining the philosophy of war and its effect on society

vii. Examining the development and improvement of armies and military art

Military history is concerned primarily about the soldier and society. It cares about how the army or other arms of the military is organized, administered and maintained. It studies strategy, tactics, communication theory, doctrine, politics, economics, geopolitics and principles of war. Military history's need to the society is innumerable. Military history may serve purposes of national integration. In this respect, military historians reconstruct national history to paint a heroic nationalistic image of the nation's soldiers whose bravery and sacrifices may have played major roles in an effort to remain a united nation or gain independence. At other times, the military historian emphasizes or sometimes exaggerates the roles of heroic soldiers of the past. This serves as a bonding force for the present and future generations. Military history probes the mentality and psychology of war captains and generals, thereby determining their impacts on events. This is to say that, if for instance a general's 
order, initially aimed at peace or integration creates a contrary situation, it is only through studying his life and times as well as probing his psychological makeup and mentality that his aspirations can better be understood. In the absence of such enquiries, it may be understood or misconstrued that his actions led or would have led to disintegration or worse still, chaos.

Military history's utility value extends to matters of policy and strategy. Knowledge of a people's military past enhances adequate strategic choices. For instance, given a situation of another war, the defunct state of Biafra would seek deeper alliances with nonIgbo communities in the South to forestall a harsh effect of a blockade and enemy invasion. Similarly, Hitler's advance into Russia was an improvement on Napoleon's earlier attempt to achieve same feat. This is one of the lessons of history. Hitler had good knowledge of the obstacles of weather and natural barriers in Russia. In the same vein, military history enables political entities determine the cost benefit of a particular war. It enables war planners determine, given the historical antecedent of the opponent, the likelihood of success or failure of a given crusade. This also enables some reduction in cost of material and life. Military history teaches how the soldier, through training, becomes what he is. It exposes and to some extent reveals that beyond the camouflage, the soldier is a man with emotions and feelings. It addresses some monstrous ascriptions to individual soldiers whose actions may have been contrary to conventional ways. For instance, military history teaches its audience that the solider kills, not because he is genetically programmed to kill, as earlier held by Lorenze, but only abides by the obligation of responding to state's security needs. He therefore, is predisposed to use his weapon, or other instrument of coercion to achieve state's obligations.

Military history is a human preservation recipe. It informs its beneficiaries about dangers of particular wars and benefits of others through reflecting over the past. Similarly, it offers clues on prospects 
of military advancement and or dynamics in technological attainments on which rests the decision on whether to embark on a particular war or desist. This is related to the role of military history in giving impetus for specific wars or serving as deterrent to others.

Military history of a state or political entity can serve sundry economic purposes. Part of this may be to serve the purpose of assessing individual nation's economic growth or decline. For instance, Eccles was able to note that in 54 BC, Julius Caesar spent about seventy five cents per man killed while in 1800 Napoleon spent about three thousand dollars, while the USA spent 21 dollars and 200 dollars per enemy killed in WWI and WWII respectively.

Military history abhors imagination. It disagrees with Doughet's declaration that preparation for war demands exercise of the imagination. Military history deals particularly on past experiences of nations or armed men of a particular nation. It places the place of imagination to insignificant proportions and deals with facts variously collected from different sources. These facts are utilized by the military historian to reconstruct events from battles, crusades and campaigns in a war or other wars. In the narrative, the military historian is mindful of his opinion in the analysis of events and facts. He is careful with choices of expression in the effort to reduce imaginary narratives. $\mathrm{He}$ is in all intents duty bound to accumulate and advance facts and ignore imaginations.

Military history is a veritable instrument of peaceful coexistence as it is also a cause for wars, if improperly handled. Often, the gory images of deaths in past wars over the years serve as a stimulator for successive generations to engage in a retaliatory war. The quest for vengeance was partly the inciting factor for the formation of the Indigenous Peoples of Biafra in South East Nigeria. Most history books on the Civil War of 1967 - 70 recreate images of deaths, by shelling and bombs as well as massive deaths by kwashiorkor. They are told in these narratives how men were shot 
without warning and how pregnant women had their foetus forcefully extracted from their belly. They were summarily told how the South east lost the crème of the society to the war. Arising from this is the continued agitation for separation. Present generation of South easterners believe that Nigerian can never be one. They argue further that the massive deaths of the 1960s marked the death of unity. This, of course, is one of the effects of military history. On the other hand, military historians of the nationalist genre are arguing that the war of 1967 - 70 was a binding force for the previously wobbling nation where political activities took to ethnic lines. They argue further that the end of the war marked the begging of sincere programmes that aimed at integrating the Nigerian nation. However this argument is viewed, military history has numerous implications for national disintegration and integration as it does for peace and disunity.

Military history has often served as stimulators for technological improvements. Because most of the narratives come with indigenous efforts at self sustenance and self defence, successive generations strive to improve on the legacies of their past heroes. The Ogbunigwe was a Biafran bomb produced to massively destroy the enemy while fighting for self preservation. It may be wrong to argue that the initial idea for its production emerged with the Civil war, rather the war threw up the exigencies of improving on the primitive indigenous technology. The Ogbunigwe was probably an improvement of what was handed down to the manufacturers by previous generations of indigenous warriors.

\section{Strategic Studies}

The discipline of strategic studies concern itself so much with the use of force, as an instrument of state policy. For Clausewitz, strategic study concerns itself with the use of engagement for the purpose of war. He further posits that war is not merely a political act, but also a political instrument, a continuation of political relations, a carrying 
out of the same by other means. Meaning therefore that wars though almost a reserve of the military, remains a political decision made usually by statesmen but executed by the military. This then creates the connection between the field of strategic studies and military science much as the later deals with the political calculations of the benefits and loses as well as justifications for military engagement; the latter is more concerned with armament, military technology and its usage. However, both are concerned with attaining:

i. The political objectives of the given political entity, say, state ii. Self preservation in the force-driven interaction with the opponent

Strategic studies according to Moltke, is the practical adoption of the means placed at a general's disposal to the attainment of the object in war. This view portrays the field succinctly as a branch of the military art, suitable only for the military general. This agrees with the Clauswizian thought that strategic studies aims at attaining a political objective of winning wars to attain the desires of the given political entity. Similarly, Liddell Hart is of the view that strategic study is the art of distributing and applying military means to fulfil the ends of policy.

During the Cold War, strategic studies became one of the most important sub-disciplines within the International Relations branch of study. This was as a result of certain developments within the international system and security environment. Most of this was the mutual competition between the two superpowers in the then seemingly bipolar international system. The issue of pronouncing the possession of nuclear weapons, weapons of mass destruction and deterrence directed the reasoning of statesmen and policy makers on how to outdo the opponents in the calculations and permutations on the use of these coercive instruments. Perhaps the absence of monopoly of knowledge of strategic studies forestalled the unimaginable. It may have served, among other factors, to deter the 
super powers during the Cold War from deploying these acclaimed weapons.

In the post Cold War international system, the focus on strategic studies intensified due perhaps to various reasons, one of which was the unpredictability of states in the pursuit of their objectives and interests in the international system. In spite of the termination of the hostilities between the West and East, it was still possible that an enemy would remain one. The issue of calculating how to survive or better still outwit the opponent in the event of an open rivalry made the issue of strategic study an indispensable area, even in post Cold War years. Nevertheless, the decline in rivalry between the superpowers ushered in the reasoning that, other issues and troubles of the world should constitute the subject of strategic studies. It was suggested for instance that HIV, poverty and related problems be added to the subject of strategic studies. Strategic studies according to Baldwin took another dimension in the 1990's. This was the era when the attention of the world shifted from systemic wars to intra state wars as well as increase in the menace of terrorism, most of which have their origin from the superpower politics of recruiting proxies against the opponent during the Cold War. There were increased cases of ethno-nationalist and intra state wars.

The end of the Cold War did not mean that nation's indolently sat to watch others attain given goals in the international system. More strategies were deployed with political, military and economic resources to attain national objectives. Nations began to form new alliances, some of which aimed at painting a dreaded image of potential enemies or they struggled to improve on their economies which invariably translated to technological (military) growth.

Critical security advocates commonly portray strategic studies as crippled by its narrow focus on Cold War era military issues. They equally condemn it based on accusation of state centricism, and as well as being west-centric. Similarly, strategic studies have been said 
to remain one of the indirect epistemological sanctions for wars. Because it teaches the craft, tactics and to some extents, art of warring and defence, critics believe that it preaches war and violence in a globalized world where social welfare and poverty eradication is or should dominate discourses. Yet strategic studies have remained a veritable tool for the success of the relatively peaceful international politics in the post Cold War era.

\section{Military History and Strategic Studies: Imperatives for National Security Development in Nigeria}

Nigerian military history dates back to British imperialism and colonialism in Nigeria. The Nigerian Army arose out of the need for constabulary forces required for order in the sphere of influence that later became colony. With the inception of colonialism, after the fall of Lagos, the British administrator of Lagos, Captain J. Glover raised 100 men known as the Lagos Constabularies. The Royal Niger Company, after earning the charter to establish its government over the Delta and Valleys of Niger and Benue raised the Royal Niger Constabulary. This force grew from 150 men in 1886 to 1000 men at the end of 1899. In spite of this rapid growth, both the British government and companies had growing dissidents and resistance within their spheres of influence, protectorates and colony.

The West African Frontier Force, an outcome of the constabulary forces, was used to quell insurrections and maintain order. It was also used to enforce and implement ordinances, as well as checking the activities of other European interests within the West African coast. More indigenous peoples were recruited during the $1^{\text {st }}$ and $2^{\text {nd }}$ World Wars when the British colonial office authorized the colonial administrative units to effect the recruitment of locals to match the rampaging menace of Hitler's ambition.

Gradually indigenous peoples flooded the army until Independence was achieved, after which the Nigerian army was 
completely taken over by the Nigerian government. At independence, the Nigerian army had a crop of soldiers most of whom had acquired British type military tradition in the International system. By virtue of this, they, despite the proclaimed non-aligned posture during the Cold War, were pro-British philosophically and politically. This equally meant that within the West African sub region, Nigerian political, economic and social interests were in alignment with British interests. This was galvanized by the conservative nature of the leadership of the First Republic, truncated by the military intervention of 15 January 1966, and marking the beginning of military rule in Nigeria.

The first military rule was six months old when it was ended by another that ruled through a ten-year period including the 3 years of Civil War. By 1976, Yakubu Gowon was removed through a bloodless coup that saw the emergence of his successor, Murtala Muhammed, whose tenure was also cut shot by another coup. The army ruled Nigeria for 29 years before the reintroduction of democratic government in 1999.

Within the periods of military rule, the Nigerian army was charged with the responsibility of protecting the country against external aggression and internal disturbances. It was equally charged with the duty of responding to the people in times of national emergency. Similarly, the Nigerian army had often maintained a posture that portrays Nigeria as the giant of Africa, especially in its interaction with other African nations. More so, it has distinguished itself, through its historical antecedents in global, continental and regional peacekeeping and enforcement operations. Similarly, the Nigerian army had responded to security issues in neighbouring African countries where it played major roles in restoring ousted legitimate governments or protecting threatened leaders.

Within the context of its military standing through a history of organized evolution and development of the Army and its achievement within the international community, the Nigerian 
military history, itself the precursor of Nigeria's strategic position, remains an imperative for security development in Nigeria for the following reasons:

- The Nigerian military history portrays an image of an army that can respond to all national emergencies.

- The history is replete with images of a country whose position within the region and around the globe stand tall among military formations.

- The Nigerian army has a history of numerical, technological and strategic growth, for which reason it remains a threat for prospective aggressors.

- The Nigerian army is an agglomeration of varied ethnic stocks for which reason it is a national institution with commitment for national security development

\section{Conclusion}

A knowledge of the Nigerian military history places one in a proper pedestal to understanding Nigeria's strategic standing, while strategic study of the Nigerian military reveals the nation's military prospects in attaining its political objectives. Both are veritable tools to attaining national security development. Distinct from many other aspects of Nigerian history, Nigerian military history is a study of development through learning and growth, during which international repute and strategic image enhance the attainment of objectives in the interaction with other national and non national players in the international system.

\section{Chiemela Godwin Wambu, PhD}

Department of History \& International Relations Abia State University, Uturu, Nigeria okeywambu009@gmail.com \& 


\section{Amaechi Ehimatie, PhD}

Department of History

College of Education

Agbor, Delta State, Nigeria

ehimatieamaechi@gmail.com

\section{References}

Baldwin, D.A. (1995). Security Studies and the End of the Cold War. In World Politics (48, no1), 117-141.

Clauswitz, Carl Von (1997). On War. Britain: Wordworth. 5-72.

Eccles, E. Henry. Logistics in National Defence. In Navel War College Review. (12, No 4, Article 5) 30.

Enuka Chuka (2015). Conflict and Peacekeeping in Africa: The West African Peace Initiative 1990 - 1997. Awka: Arise and Shine Press, $8-10$.

Hart, Liddel B.H. Strategy. New York: Fredrick A. Preager. 14-33.

Igwe, Obasi (1989). A Modern Introduction to strategic Studies. Nigeria: National Library of Nigeria Cataloguing in Publication Data, 54-57.

Imobighe, T.A. (2006). Rethinking Terrorism and Counter Terrorism.

In T.A. Imobighe, and A. Egwuavon (Eds.), Terrorism and Counter Terrorism: An African Perspective (p. 7) Ibadan: Heinemann Educational Books.

Lorenz, Conrad (1966). On Aggression. New York: Harcourt, Brace and World.

Moltke, Von. The Art of War (2011) Retrieved from Wikipedia on 20/10/11.

NAECS (1992). History of the Nigerian Army 1863 - 1992. Abuja: Gabumo Pub. Comp. 30-70.

Shaibu, A. Margaret (2018). What Distinguishes Military History. Retrieved from https://www.academia.edu on 11/8/2018. 
Suchy, Peter. Role of Security and Strategic Studies within International Relation Studies. Retrieved from mocr.army.c2/mo/obrana-a-strategy, on 30/10/2019.

Ukpabi, S.C. (1980). The Nigerian Armed Forces - Growth, Development, and Potentials-Historical perspective. In S.C. Ukpabi (Ed.) Strands in Nigerian Military History. Zaria: Gaskiya Corporation Ltd.

Ukpabi, S.C. (1986). Strands in Nigerian Military History. Zaria: Gaskiya Corporation Ltd.

Vennesson, Pascal (2017). Is Strategic Studies Narrow? Critical Security and the Misunderstood Scope of Strategy. In Journal of Strategic Studies (40).

Walt, S.M. (1991). The Renaissance of Security Studies. In International Studies Quarterly, Marshon Services (35, no 1), 211-239. 